${ }^{1)}$ Masachussetsky institute of technology, New York, USA; ${ }^{2)}$ National Technical University of Ukraine "Igor Sikorsky Kyiv Polytechnic Institute", Kyiv, Ukraine

STABLE RESHAPERS OF IMPULSIVE CURRENT FOR THE POWER SUPPLY OF LIGHTEMITTING DIODES

Stable generators of light impulses nano and subnanosecond duration can find a wide usage in an experimental technique, instrument-making. As a light source in such generators it is perspective to use stable, broadband, fast-acting light-emitting diodes on the basis of carbide of silicon, working in the mode of electric break-down. There is a necessity of creation of stable reshapers of pulse current for their power supply. A objective of this paper is creation of such reshapers on the basis of the avalanche and high-speed field-effect transistors.

A lot of types and copies of inexpensive epitaxial transistors working in the avalanche mode is tested. The optimal interval of break-down voltages of collector junction is experimentally determined. Temporal instability of reshapers on avalanche transistors is investigated. Behaviour of their ageing(degradation) is studied. The circuit design of reshaper on the field transistor working by avalanche transistor control is developed. That allows to form the subnanosecond impulses of current through light-emitting diodes by amplitude to $1 \mathrm{~A}$.

Keywords: impulse shaper of current, light-emitting diode, silicon carbide, avalanche transistors.

Надійшла до редакиії 23 травня 2016 року

Рецензовано 06 червня 2015 року

(C) Аушев С. В., Воронов С. О., Генкін О. М., Генкіна В. К., Родіонов В. М., 2016

УДК 621.382(075.8)

\title{
INFRARED DETECTORS BASED ON TERNARY SEMICONDUCTOR QUANTUM STRUCTURES
}

\author{
Saurova T., Baida I. \\ National Technical University of Ukraine "Igor Sikorsky Kyiv Polytechnic Institute", Kyiv, \\ Ukraine \\ E-mail: saurowa@phbme.kpi.ua; irinebd8@gmail.com
}

The development of growth process of multilayer semiconductor structures enables investigation of a new class of infrared detectors - detectors on quantum structures. The current trends of infrared receivers' development are caused by active material research for a variety of nanostructures. The current state of development of infrared quantum structure detectors using ternary semiconductor alloys is considered. The maximal detectivity values of traditional detectors and quantum structure detectors are presented. The analysis of parameters for different types of materials and structures is performed.

Keywords: infrared photodetectors; bulk detectors; quantum well infrared detectors; quantum dot infrared detectors; superlattices; detectivity.

\section{Introduction}

Recent achievements in combining new materials have introduced the alloys of binary compounds $\left(A^{2} B^{6}, A^{3} B^{5}, A^{4} B^{6}\right)$ to the list of materials suitable for detection. Ternary semiconductor alloys are widely used for creating semiconductor devices. By changing material composition researchers can manipulate the properties of material, and even obtain materials with new qualities.

Cutting-edge advances in microelectronics technology in mid-to-late XX century contributed to the creation of devices with elements of a micron size. At the present stage of semiconductor electronics nanoelectronics - new elements whose dimensions are reduced by several orders of magnitude are created. The principal difference between elements of nanoelectronics and microelectronics is in existing quantum effects. Multi-component semiconductor compounds of the varying composition expand opportunities to create nanoscale structures: superlattices, quantum wires, quantum dots. The efforts of many research groups are aimed at creating new objects based on such structures: devices and systems with improved performance. 


\section{Ternary alloy detectors}

\subsection{Traditional Detectors}

For more than two centuries, the infrared radiation (IR) is the object of study: finding ways of detecting and applying it. Researchers distinguish the near (NIR; 0,7-1,0 $\square \mathrm{m}$ ), short wavelength (SWIR; 1,0-3 $\square \mathrm{m}$ ), middle wavelength (MWIR; 3-5 $\square \mathrm{m}$ ), long wavelength (LWIR; 8-12 $\square \mathrm{m}$ ) and very long wavelength (VLWIR; 12-30 $\square \mathrm{m}$ ) regions of the infrared spectral range. Infrared radiation is absorbed by the molecules of different substances contained in the atmosphere. This characteristic is the basis of chemical sensors operation and is taken into account in development of receivers for different purposes. Infrared detectors are in demand for military and civil applications (astronautics, environmental monitoring, industrial and technological processes, medicine, fiber-optic systems, night vision devices, monitoring system of moving and static objects, etc.).

At present, $\mathrm{HgCdTe}$ is the most widely used semiconductor material, which allows creating high performance infrared photodetectors. The most common parameters of single element infrared detectors are normalized detectivity $D^{*}$, sensitivity, dark current and operating temperature. They have been determined by electronic, optical, thermal and mechanical properties of used materials. $D^{*}=D \sqrt{A \cdot \Delta f}=\frac{\sqrt{A \cdot \Delta f}}{N E P}$, where $D$ is a detectivity, $A$ is a cross-sectional area of the detector, $\Delta f$ is a bandwidth of the device, NEP power level of optical signal at that signal-to-noise equals to 1 [1].

Demand of $\mathrm{Hg}_{1-x} \mathrm{Gd}_{x}$ Te as a material basis for IR detectors development is associated with:

- ability to change the width of energy gap $\Delta E$ in a wide range;

- low dielectric constant;

- low value of electron effective mass;

- weak dependency of the lattice constant value on composition variation $x$;

- a wide range of operating temperatures.

By changing the molar composition $x$ of ternary semiconductor alloy the dependence of the energy gap $\Delta E$ on alloy composition and temperature $T, K$ can be obtained for $\operatorname{HgTe}(x=0)$ and CdTe $(x=0)$ as in [2]

$$
\begin{gathered}
\Delta E=-0,302+1,93 x-0,81 x^{2}+0,832 x^{3}+ \\
+5,35 \cdot 10^{-4} T(1-2 x) .
\end{gathered}
$$

Thus, molar composition $x$ of ternary alloy defines the cutoff detector wavelength $\lambda[\mu \mathrm{m}]=1,24 / \Delta E$.

The main drawbacks of this material are: difficulty of obtaining the uniform composition of the material and the thickness of the sample; small size of grown wafers; high dark currents; high concentration of intrinsic point defects and other crystal inhomogeneity [1]. All these problems lead to a low yield rate of operable arrays and high costs of the matrix formers of IR image.

During the development of $\mathrm{HgCdTe}$-based IR detectors the researchers have been looking for alternative materials because of emerging technological issues. Ternary semiconductors based on alloys of binary compounds $\mathrm{A}^{4} \mathrm{~B}^{6}, \mathrm{~A}^{3} \mathrm{~B}^{5}$ and $\mathrm{A}^{2} \mathrm{~B}^{6}$ were considered as alternative materials.

The most promising $\mathrm{A}^{4} \mathrm{~B}^{6}$ candidate was $\mathrm{PbSnTe}$ [1]. Up till the 1970s the technology of the creating IR detectors based on PbSnTe has been extensively developed: devices with high detectivity in the LWIR spectral range are designed. However, in contrast to $\mathrm{Si}$ high static dielectric constant and high thermal expansion coefficient are revealed. The high static dielectric constant leads to high capacity of photodiodes and respectively to limiting the frequency properties of scanning systems based on them. Overcoming the second drawback required additional studies for the development of image generation systems. These properties of solid PbSnTe led to less researches and development of IR systems based on it [3]. However, in the early XXI century photodetector with high de-

tectivity $D^{*}$ based on high-doped PbSnTe was developed.

The studies of ternary $\mathrm{A}^{3} \mathrm{~B}^{5}$ semiconductor alloys are held for InSb and InAs with insertion of thallium $\mathrm{Ti}$, bismuth $\mathrm{Bi}$, arsenic $\mathrm{As}$, nitrogen $\mathrm{N}$, gallium $\mathrm{Ga}$, phosphorus $\mathrm{P}$. The highest detectivity values $D^{*}$ are obtained for devices based on $\operatorname{InAs}_{1-x} \mathrm{Sb}_{x}$ [4].

The insertion of arsenic in binary compound $\mathrm{InSb}$ allowed simplifying the development of IR detectors for required wavelengths. InAsSb was the promising candidate for detectors development in SWIR, MWIR, LWIR spectral ranges [1]. However, the technical issues of growing the single crystals and epitaxial layers were mainly solved only to the extent the development of molecular beam epitaxy and chemical vapor deposition of organometallic compounds methods. The technologies, mentioned above, have also contributed to the improvement the characteristics of GaInAs-based devices. The dependency of the energy gap $\Delta E$ on composition structure determines the ability to operate of detectors in the NWIR, SWIR, MWIR ranges. Designing of $\mathrm{p}$-i-n structures with the low dark current over a wide frequency range makes the material in demand in the NWIR range for various applications. Improved technologies, long-term practical experience allowed developing of IR detectors on ternary alloy InGaAs with the best characteristics in the NWIR, SWIR ranges $[5,6]$. Advancing in the MWIR range issue of creating high-performance devices is being more complicated due to significant increase of dark current and surface leakage current. The use of InGaAs in alternative detecting structures (i.e. quantum structures) made the 
designing of high-quality IR systems (monolithic and hybrid architecture) of the SWIR, MWIR and LWIR possible.

In 1990s, the attention of IR detectors developers was focused on ternary semiconductor alloys contained mercury (HgZnTe, HgMnTe). Numerous studies have indicated that the active development of growing technology will allow creation of the high quality IR detectors in the SWIR range (and even higher) with highly stable performance and long lifetime on the basis of such alloys [6, 7, 8, 9]. However, the development of HgZnTe-based IR detectors took place only in the period from the mid-80s to the end of the XX century.

For the remainder of our article, we shift our attention to modern trends of development of quantum infrared detectors, contained ternary alloy semiconductors.

\subsection{Quantum Structure Detectors}

During the development of nanoelectronics a class of detectors using quantum effects in quantum well structures (QWS), superlattice structures (SLS), quantum dot structures (QDS) for registration of IR radiation, was formed.

The idea of creating IR detectors on QWS belongs to authors of works $[10,11]$. Structurally QWS detector is a layered semiconductor microstructure, whose small geometric dimensions lead to quantization of electron states in them. The simplest QWS is a periodic repetition of layers of two semiconductor materials with different energy gaps. Potential relief determines the movement of the carriers towards the crystal growth direction. The form of potential relief is described by a periodic sequence of wells and barriers. The wells are formed in the narrow-gap material of the structure, while barriers are formed in the material with a greater energy gap. The quantum effect manifests itself when the thickness of the well is comparable with the de Broglie wavelength: a discrete set of energy states is formed in the well. In simple the principle of IR detector in such structure is explained by excitation $E_{l}$ of the carriers in the ground energy state $E_{0}$ (Fig. 1).

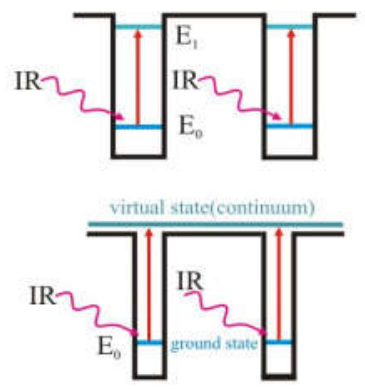

Fig 1. Infrared detector with structure of quantum wells: the operation mechanism

Selection of structural parameters which is required for operation of the IR detectors on quantum wells is based on the size quantization characteristics [12]:

- a finite height quantum well contains a finite number of quantized states;

- if the width of a single quantum well is reduced, the first excited state leaves the well and becomes a virtual state (continuum);

- the electron wave functions do not vanish at the boundary; they penetrate the barrier and decrease there exponentially.

The first characteristic of size quantization allows managing the size of the QWS IR detector terminal working wavelength. The second characteristic explains the possible photoexcitation modes of the carriers and the corresponding form of the spectral dependences. The narrow spectrum is typical for photoexcitation during "bound state - bound state" transitions, the wide spectrum - during "bound state - virtual state (continuum)" transitions.

The third characteristic of size quantization explains the fundamental restructuring of the QWS band diagram when thickness of the barriers is reduced: overlapping of the carrier wave functions allows forming the energy subzones (minizones) (Fig. 2). QWS is transformed into SLS. In SLS the period of alternating semiconductor layers far exceeds the lattice constant, but does not exceed the free run distance of the electrons. The principle of a detector superlattice structure is based on intersubband absorption of infrared radiation.

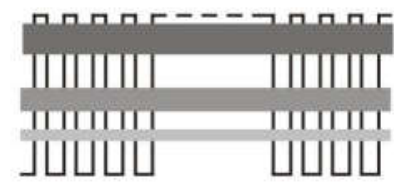

Fig. 2. Minibands formation in the superlattice

The quantum effects manifest themselves even more in the quantum dot structures, where movement of carriers is limited in three directions. The QDS energy spectrum is similar to nuclear. The principle of a quantum dot structure based IR detectors is analogous to the QWS detectors (Fig. 3).

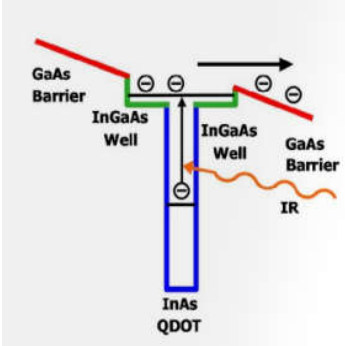

Fig. 3. The principle of IR detector with a dot structure in quantum wells [13]

Development of the QWS, SLS, QDS based IR detector is actively conducted since the late $\mathrm{XX}$ century. The most common ternary alloy semiconductors to build QWS detectors are: $\mathrm{Al}_{x} \mathrm{Ga}_{1-x} \mathrm{As}, \mathrm{In}_{x} \mathrm{Ga}_{1-x} \mathrm{As}$, 
$\operatorname{In}_{x} \mathrm{Ga}_{1-x} \mathrm{Sb}, \mathrm{In}_{x} \mathrm{As}_{1-x} \mathrm{Sb}, \mathrm{In}_{x} \mathrm{Al}_{1-x} \mathrm{As}$, GaInP, AlInP. The following systems are used on their basis $\mathrm{GaAs} / \mathrm{Al}_{x} \mathrm{Ga}_{1-x} \mathrm{As}$, GaAs/GaInP, GaAs/AlInP, $\mathrm{In}_{x} \mathrm{Ga}_{1-}$ ${ }_{x} \mathrm{As} / \mathrm{In}_{x} \mathrm{Al}_{1-x} \mathrm{As}, \quad \operatorname{InAs} / \mathrm{In}_{x} \mathrm{Ga}_{1-x} \mathrm{Sb}, \quad \mathrm{InSb} / \mathrm{In}_{x} \mathrm{As}_{1-x} \mathrm{Sb}$, $\mathrm{In}_{x} \mathrm{Ga}_{1-x} \mathrm{As} / \mathrm{InP}$. Each pair of a system is formed of the materials with different energy gaps but with consistent lattice constants. Changing the composition of the ternary alloy provides control over the (conductivity, valence) band gap at the separation boundary between the contacting semiconductors, i.e. over the height of the potential barrier which is formed along the layered structure. The thicknesses of the structure layers determine the width of the quantum well (barrier). The calculated dependencies shown on Fig. 4 show: the picture of discrete energy states in a well is defined by the structure layer thicknesses and the molar composition of the ternary alloy $[13,14]$.
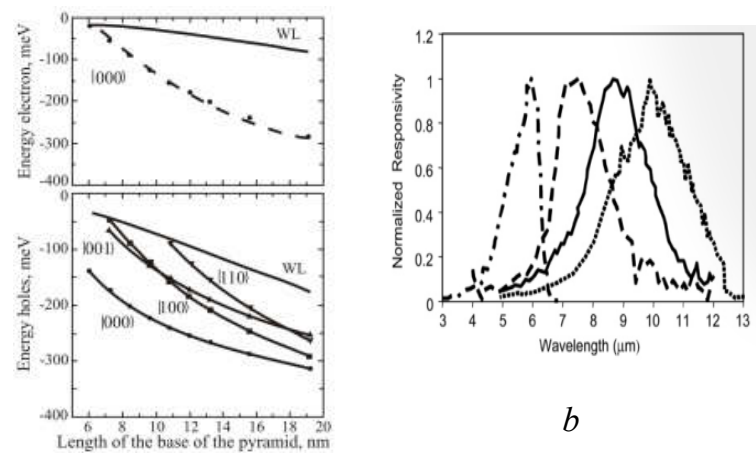

a

Fig. 4. a dependence of the electron ground state energy as well as ground state and excited state energy of the hole, as a function of the quantum dot base size [14], b experimentally measured spectral responsivity of QD IR detectors demonstrating spectral tunability by varying the well width from 55 to $100 \AA$ [13]

Thus, controlling the parameters of the quantum structure (taking into account external factors) allows developing the detectors for various ranges of the IR spectrum. It should be noted that the n-type QWS detectors has a significant disadvantage: insensitivity to the normally falling IR radiation. The p-type QWS detectors do not have this disadvantage, but their characteristics are inferior to the corresponding characteristics of the n-type. Additional devices (lattices) are used in the n-type QWS detectors for registration of the normally falling IR radiation.

The start of research of the lattice structures was initiated in the first work of L. Esaki and R. Tsu [15]. In the work by Herman [16] classification of these structures is introduced, according to which the type II SL are preferred for construction of the IR detectors. They are characterized by the spatial separation of the carriers: electrons and holes are concentrated in different semiconductor layers. At the present stage SL with a various profile of superlattice potential $[17,18,19]$ as well as SL with strained layers (SLSL) [20, 21, 22] are developed, to improve the characteristics of the device. An SLSL is based on the use of materials with mismatching lattice constant values. The elastic strains arising in SLSL allow growing of the highquality structures. The first SLSL-based detector was designed in the mid-1990s.

In 1993 success has been achieved (without defects) in growing of a nanostructure with quantum dots [23]. This marked the beginning of research in designing of QDS-based IR detectors. At the present time ternary alloys are also used for cultivation of structures with quantum dots: InGaAs (quantum dot, barrier layer); AlGaAs, InGaP (barrier layer). The energy spectrum of the quantum dot is largely determined by its size. Changing the molar composition of the quantum dot material, as well as of barrier layer material, creates an additional way to control the energy spectrum of a quantum system. In accordance with the construction principle the QDS IR detectors may have a narrow spectral response, low dark current, high detectivity $D^{*}$. With an ability to absorb the normally falling IR radiation the QDS detectors becomes an attractive target for a wide range of applications.

\subsection{The Maximal DetectivityValues of Ternary} Alloy Detectors

The Table 1 shows the maximal detectability values $D^{*}$ of the IR detectors based on traditional and quantum structures which utilize ternary semiconductors.

The detectors based on $\mathrm{HgCdTE}$ and InAsSb have the highest values of $D^{*}$ in a wide range of the IR spectrum among the conventional devices, with the first prevailing in LWIR and VLWIR ranges, and the second prevailing in the NWIR range. The highest value of $D^{*}$ corresponds to PbSnTe based PD in the VLWIR range, while GaInAs is an unmatched ternary semiconductor in the SWIR range.

The efforts of QWS IR PD developers are focused on the SWIR, SWIR and LWIR ranges. Researches and developments are carried out using a large number of ternary semiconductors. AlGaAs (MWIR, LWIR, VLWIR) and InGaAs (SWIR, MWIR, LWIR) are represented in the widest range of the IR spectrum. The highest values of $D^{*}$ in the SWIR range are achieved in devices based on AlAsSb. InAlAs, InGaAs and AlGaAs are the best materials in the MWIR range, their $D^{*}$ being close to or even higher than the corresponding values of widely used detectors.

Detectors based on the superlattices and quantum dot structures with the use of ternary alloy semiconductors are the latest areas of development. Excellent results were obtained for SLS that use GaInSb. A high $D^{*}$ value for a QDS detector on InGaP was obtained. Theoretical predictions are presented in [22]. 


\section{Conclusions}

The performed analysis of the development of the IR photodetectors based on ternary semiconductor alloys showed that

- InAsSb (for NWIR, SWIR, LWIR, VLWIR spectral regions), GaInAs (for SWIR region), $\mathrm{PbSbTe}$ (for VLWIR spectral window) are the alternative materials for conventional structures.
- AlGaAs (for SWIR, MWIR, LWIR, VLWIR spectral regions), InGaAs (for SWIR, MWIR, LWIR), GaInSb (for LWIR and VLWIR regions), InGaP (for MWIR) are the variant materials for development of quantum structure detectors.

- Using ternary semiconductor alloys extends potential in IR systems development.

Table 1 . The maximal detectivity values $D^{*}$

\begin{tabular}{|c|c|c|c|c|c|c|}
\hline \multirow{2}{*}{ IRPD } & \multirow{2}{*}{ material } & \multicolumn{5}{|c|}{$D^{*}, \mathrm{cmHz}^{1 / 2} \mathbf{W}^{-1}(T, K)$} \\
\hline & & NWIR $(0.7-1 \mu \mathrm{m})$ & SWIR (1-3 $\mu \mathrm{m})$ & MWIR (3-5 $\mu \mathrm{m})$ & LWIR (5-8 $\mu \mathrm{m})$ & VLWIR $(12-30 \mu \mathrm{m})$ \\
\hline \multirow{8}{*}{ 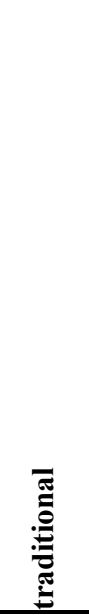 } & HgCdTe & $\begin{array}{l}10^{10}(230) ;[24] \\
1,2 \cdot 10^{9}(300) ;[24]\end{array}$ & $\begin{array}{l}10^{14}(77) ;[25] \\
10^{12}(300) ;[25]\end{array}$ & $\begin{array}{l}2 \cdot 10^{13}(77) ;[25] \\
7 \cdot 10^{10}(210) ;[26]\end{array}$ & $\begin{array}{l}2 \cdot 10^{13}(77) ;[25] \\
10^{7}(300) ;[27]\end{array}$ & $10^{10}(77) ;[28]$ \\
\hline & InAsSb & $10^{14}(300) ;[29]$ & $\begin{array}{l}10^{14} ;[29] \\
2 \cdot 10^{13}(130) ;[30]\end{array}$ & $\begin{array}{l}3 \cdot 10^{11}(77) ;[31] \\
5 \cdot 10^{9}(200) ;[31]\end{array}$ & $\begin{array}{l}1,5 \cdot 10^{8}(300) ;[34] \\
3 \cdot 10^{10} ;[35]\end{array}$ & $1,5 \cdot 10^{8}(300) ;[34]$ \\
\hline & HgZnTe & & $\begin{array}{l}7 \cdot 10^{10}(300) ;[14] \\
8 \cdot 10^{11}(77) ;[14]\end{array}$ & $\begin{array}{l}9 \cdot 10^{10}(300) ;[12] \\
4 \cdot 10^{11}(77) ;[12]\end{array}$ & $1,2 \cdot 10^{11}(77) ;[34]$ & $\begin{array}{l}8 \cdot 10^{10}(65) ;[7] \\
10^{6}(300) ;[12]\end{array}$ \\
\hline & InGaSb & $\left.5,5 \cdot 10^{10}(300) ; 37\right]$ & $5,5 \cdot 10^{10}(300) ;[7]$ & & & \\
\hline & GaInAs & $10^{13}(300) ;[5]$ & $\begin{array}{l}1,1 \cdot 10^{15}(195) ;[36] \\
1,5 \cdot 10^{13}(300) ;[36]\end{array}$ & & & \\
\hline & InSbBi & & & & $4,7 \cdot 10^{8}(77) ;[37]$ & \\
\hline & PbSnTe & & & $0,8 \cdot 10^{10}(77) ;[12]$ & $2 \cdot 10^{10}(77) ;[12]$ & $\begin{array}{l}10^{16}(7) ;[38] \\
8,7 \cdot 10^{12}(21) ;[39]\end{array}$ \\
\hline & HgMnTe & & & & $* * * *$ & $* * * *$ \\
\hline \multirow[b]{7}{*}{2} & InGaAs & & $\begin{array}{l}5,6 \cdot 10^{10}(200) ;[40] \\
3,8 \cdot 10^{9}(295) ;[40]\end{array}$ & $\begin{array}{l}1,2 \cdot 10^{11}(108) ;[41] \\
10^{7}(300) ;[42]\end{array}$ & $\begin{array}{l}10^{11}(40) ;[34] \\
1,3 \cdot 10^{10}(100) ;[43]\end{array}$ & $1,8 \cdot 10^{10}(40) ;[44]$ \\
\hline & AlGaAs & & & $\begin{array}{l}10^{11}(210) ;[45] \\
1,1 \cdot 10^{12}(77) ;[46]\end{array}$ & $\begin{array}{l}2 \cdot 10^{11}(77) ;[47] \\
10^{11}(77) ;[48]\end{array}$ & $\begin{array}{l}3 \cdot 10^{10}(50) ;[49] \\
8 \cdot 10^{13}(33) ;[49]\end{array}$ \\
\hline & AlAsSb & & $1,1 \cdot 10^{12}(100) ;[43]$ & $2,5 \cdot 10^{10}(80) ;[50]$ & & \\
\hline & GaAsSb & & $\begin{array}{l}5,6 \cdot 10^{10}(200) ;[40] \\
3,8 \cdot 10^{9}(295) ;[40]\end{array}$ & $2 \cdot 10^{8}(290) ;[51]$ & & \\
\hline & InAlAs & & & $\begin{array}{l}1,3 \cdot 10^{11}(100) ;[43] \\
1 \cdot 10^{7}(300) ;[42]\end{array}$ & $1,3 \cdot 10^{10}(100) ;[43]$ & \\
\hline & InGaSb & & & & $10^{10}(130) ;[52]$ & \\
\hline & InAsSb & & $* * * *$ & $* * * *$ & & \\
\hline \multirow{3}{*}{$\sqrt[\infty]{\infty}$} & AlGaAs & & & & $\begin{array}{l}5,4 \cdot 10^{11}(4) ;[53] \\
1,6 \cdot 10^{10}(77) ;[54]\end{array}$ & $\begin{array}{l}2 \cdot 10^{9}(60) ;[56] \\
10^{10}(20) ;[56]\end{array}$ \\
\hline & GaInSb & & & & $10^{12}(77) ;[55]$ & $10^{12}(77) ;[55]$ \\
\hline & InAsSb & & & $* * * *$ & $* * * *$ & $* * * *$ \\
\hline \multirow[b]{3}{*}{$\hat{\sigma}$} & AlGaAs & & $10^{9} ;[57]$ & $10^{10}(77) ;[58]$ & $10^{10}(130) ;[59]$ & $10^{10}(130) ;[59]$ \\
\hline & InGaAs & & & $10^{10}(77) ;[60]$ & $10^{11} ;[61]$ & \\
\hline & InGaP & & & $\begin{array}{l}10^{12}(77) ;[62] \\
2,4 \cdot 10^{8}(250) ;[56]\end{array}$ & & \\
\hline
\end{tabular}

\section{References}

1. A. Rogalski, Prog. Quantum Electron., 27, 2003, pp. 59-210

2. G. L. Hansen, J. L. Schmit, T. N. Casselman J. Appl. Phys. vol. 53, 1982, pp. 7099-7101.
3. A. E. Klimov, V. N. Shumsky, Matrix photoreceivers infrared. Novosibirsk, Russia: The science, 2001

4. D. Lackner, O. J. Pitts, M. Martine, Y. T. Cherng, P. M. Mooney, M.L.W. Thewalt, E. Plis, S. P. Watkins, Proceedings of the International Conference 
on Indium Phosphide and Related Materials, Kagawa, Japan, 2010, pp. 1-4

5. Sensors Unlimited, www.sensorsinc.com

6. A. Rogalski, Prog. Quant. Electr. vol. 13, 1989, pp. 299-253

7. R. Triboulet, M. Bourdillot, A. Durand, T. Nguyen Duy, Proc. SPIE, 1989, pp. 40-47

8. R. Triboulet, J. Cryst. Growh, vol. 86, 1988, pp. 79-86

9. R. Triboulet, A. Lasbley, B, Toulouse, J. Cryst. Growth, vol. 76, 1986, pp. 695-700

10.J. C. Smith, L. C. Chiu, S. Margalit, A. Yariv, A. Y. Cho, J. Vac. Sci. Technol. B1, 1983, pp. 376-378

11. L. C. Chiu, J. S. Smith, S. Margalit, A. Yariv, A. Y. Cho, Infrared Phys. vol. 23, 1983, pp. 93-97

12. A. Rogalski "Infrared Detectors", Sibirian Publishing House of the Russian Academy of Sciences, 2003

13.S. D. Gunapala, S. V. Bandara, C. J. Hill, D. Z. Ting, J. K. Liu, S. B. Rafol, E. R. Blazejewski, J. M. Mumolo, S. A. Keo, S. Krishna, Y. C. Chang, C. A. Shott, IEEE J. Quantum Electron, vol. 43, 2007, pp. 230-237.

14. N. N. Ledentsov, V. M. Ustinov, V. A. Shchukin, P. S. Kop'ev, and Zh.I. Alferov, St. Petersburg, Russia: A.F. Ioffe Physicotechnical Institute, Russian Academy of Sciences: Physics and technique of semiconductors, tom 32, Issue 4, pp.385-410, 1998

15. L. Esaki, R. Tsu, IBM J. Res. Dev., 14, 1970, p. 61

16. M. A. Herman, Moscow: Publishing World, 1989

17. K.M.S.V. Bandara, J. W. Choe, M. H. Francombe, A.G.U. Perera, Y.F. Lin, Appl. Phys., vol. 60, 1992, pp. 3022-3024

18. S. D. Gunapala, B. F. Levine, N. Chand, J. Appl. Phys., vol. 70, 1991, pp. 305-308

19.S. S. Li, M. Y. Chuang, L. S. Yu, Semicond. Sci. Technol. 8, 1993, pp. 406-411

20. G. J. Brown, Proc. SPIE., vol. 5783, 2005, pp.65-77

21. G. E. Bulman, D. R. Myers, J. J. Wiczer, L. R. Dawson, R. M. Biefeld, T. E. Zipperian, IEEE Electron. Devices Meet. vol. 30,1984, pp.719-722

22. A. Rogalski, Proc. SPIE7388, Ninth International Conference on Correlation Optics, 73880J (31 December 2009), doi:10.1117/12.852524

23.D. Leonard, M. Krishnamurthy, C. M. Reaves, S. P. Denbaars, P. M. Petroff, Appl. Phys. vol. 63, 1993, pp.3203-3205.

24. http://www.vigo.com.pl/products/infrareddetectors

25. L. J. Kozlowski, Proc. SPIE. vol. 3179, 1997, pp. 200-211

26. V. V. Vasilyev, V. N. Ovsyuk, Y. G. Sidorov, Proc. SPIE., vol. 5065, 2003, pp.39-46.

27.J. Piotrowski, A. Rogalski, Proc. SPIE, vol. 5359, 2004, pp.10-22.

28. http://www.hamamatsu.com/

29.I. D. Burlakov, L. I. Grinchenko, A. I. Dirochka, N. B. Zaletaev, Advances of Applied Physics, № 2, vol. 2, 2014, pp. 131-162

30. L. J. Kozlowski, S. A. Cabelli, D. E. Cooper, K. Vural, Proc. SPIE 1946, 1993, pp. 199-213
31.S.K.H. Sim, H. C. Liu, A. Shen, M. Gao, K. F. Lee, M. Buchanan, Y. Ohno, H. Ohno, E. H. Li, Infrared Phys. Technol, vol. 42, 2001, pp.115-121.

32.J. D. Kim, S. Kim, D. Wu, J. Wojkowski, J. Xu, J. Piotrowski, E. Bigan, M. Razeghi, Applied Physics Letters, vol. 67, 1995, pp. 2645-2647

33. C. G. Bethea, M. Y. Yen, B. F. Levine, K. K. Choi, A. Y. Cho, Appl. Phys., vol. 51, 1987, pp. 1431-1432.

34. A. Singh, M.O. Manasreh, Proceedings of SPIE 2397, 1995, pp. 193-209.

35.F. Refaat Tamer, M. Nurul Abedin, N. Singh Upendra, Vinay Bhagwat, B. Bhat Ishwara, S. Dutta Partha, Proc. SPIE 7388, Ninth International Conference on Correlation Optics, 73880J (31 December 2009), doi:10.1117/12.852524.

36. L. J. Kozlowski, K. Vural, J. M. Arias, W. E. Tennant, R. E. DeWames, Proceedings of SPIE 3182, 1997, pp. 2-13.

37.J.J. Lee, M. Razeghi, Opto-Electronics Review, vol. 6, 1998, pp. 25-3.

38. A. E. Klimov, V. N. Shumsky, J. Optical 76, 2009 , pp. 12-19.

39. A. N. Akimov, A. A. Belenchuk, A. A. Klimov, M. M. Kachanova, I. G. Neizvestnuj, S. P. Suprun, O. M. Shapoval, V. N. Sherstyakova, V. N., Tech. Phys. Lett., tom 35, Issue 11, pp. 88-95.

40. Rubin Sidhu Certifies, Dissertation: Presented to the Faculty of the Graduate School of the University of Texas at Austin, in Partial Fulfillment, of the equirements, for the degree of doctor of philosophy, The University of Texas at Austin, December 2005.

41.F. R. Giorgetta, E. Baumann, R. Th?ron, M. L. Pellaton, D. Hofstetter, M. Fischer, J. Faist, Appl. Phys. Lett. 92, 2008, p.121101.

42. Wang Xuejiao, Liu Junqi, Zhai Shenqiang, Liu Fengqi, Wang Zhanguo, Journal of Semiconductors, Vol. 35, No. 10, 2014, p.104009.

43. D. Hofstetter, F.R. Giorgetta, E. Baumann, Q. Yang, C. Manz, K. K?hler, Applied Physics B: Lasers and Optics, Vol. 100, Issue 2, 2010, pp. 313-320.

44. S.D. Gunapala, K.M.S.V. Bandara, B.F. Levine, G. Sarusi, J.S. Park, T.L. Lin, W.T. Pike, J.K. Liu, Appl. Phys. Lett. 64, 1994, pp.3431-3433.

45. T. Oogarah, H.C. Liu, E. Dupont, Z.R. Wasilewski, M. Byloos, M. Buchanan, Semicond. Sci. Technol., vol. 17, 2002, pp.41-43.

46. B.F. Levine, S.D. Gunapala, R.F. Kopf, Appl. Phys. Lett., vol. 58, 1991, pp. 1551-1553.

47. S.D. Gunapala, S.V. Bandara, J.K. Liu, E.M. Luong, N. Stetson, C.A. Shott, J.J. Bock, S.B. Rafol, J.M. Mumolo, M.J. McKelvey, IEEE Trans. Electron. Devices. 47, 2000, pp. 326-332.

48. A. Rogalski, Infrared Physics and Technology, vol. 40, 1999, pp. 279-294.

49. A. Zussman, B.F. Levine, J.M. Kuo, J. de Jong, J. Appl. Phys., vol. 70, 1991, pp. 5101-5107.

50. Arvind Pawan Ravikumar, Thor A. Garcia, Joel De Jesus, Maria C. Tamargo, Claire F. Gmachl, CLEO: 2014 OSA Technical Digest, 2014, paper STu3G.4, doi:10.1364/CLEO_SI.2014.STu3G.4 
51. Baile Chen, W.Y. Jiang, Jinrong Yuan, L. Archie, Holmes, B.M. Onat, IEEE Photonics Technology Letters, Volume 23, Issue 4, FEBRUARY 15, 2011, pp. 218-220.

52.S.R. Kurtz, L.R. Dawson, T.E. Zipperian, R.D. Whaley, IEEE Electron Device Letters 11, 1990, pp. 54-56.

53. B.F. Levine, S.D. Gunapala, N. Chand, J. Appl. Phys., vol. 70, 1991, pp.305-308.

54.L.S. Yu, S.S. Li, Appl. Phys. Lett. 59, 1991, pp. $1332-1334$

55. F. Fuchs, U. Weimer, W. Pletschen, J. Schmitz, E. Ahlswede, M. Walther, J. Wagner, P. Koidl, Applied Physics Letters, vol. 71, 1997, pp. 3251-3253.

56. S.F. Tang, S.Y. Lin, S.C. Lee, Appl. Phys. Lett. 78, 2001, pp. 2428-2430.

57.Z.H. Chen, O. Baklenov, E.T. Kim, I. Mukhametzhanov, J. Tie, A. Madhukar, Z. Ye, J.C. Campbell, Infrared Phys. Technol. 42, 2001, pp. 479-484.
58. Zhengmao Ye, Joe C. Campbell, Zhonghui Chen, Eui-Tae Kim, Anupam Madhukar, IEEE JOURNAL OF QUANTUM ELECTRONICS, Vol. 38, № 9, september 2002, pp. 1234-1237.

59. S.D. Gunapala, D. Ting, S.V. Bandara, C. Hill, E. Blazejewski, S. Krishna, Sir Rafol, SPIE Newsroom 10.1117/2.1200803.1043.

60. S. Krishna, S. Raghavan, G. von Winckel, A. Stintz, G. Ariyawansa, S.G. Matsik, A.G.U. Perera, Appl. Phys. Lett. 83, 2003, p. 2745, doi: 10.1063/1.1615838.

61.S. Chakrabarti, S. Adhikary, N. Halder, Y. Aytac, A.G.U. Perera, Appl. Phys. Lett. 99, 2011, p. 181102.

62.J. Szafraniec, S. Tsao, W. Zhang, H. Lim, M. Taguchi, A.A. Quivy, B. Movaghar, M. Razeghi, Appl. Phys. Lett. 88, 20 March 2006, p. 121102, doi: $10.1063 / 1.2188056$.

\section{УДК 621.382(075.8)}

\section{Т. А. Саурова, І. П. Байда}

Наиіональний технічний університет Украӥни «Київський політехнічний інститут імені Ігоря Сікорського», м. Київ, Україна ІНФРАЧЕРВОНІ ДЕТЕКТОРИ НА ОСНОВІ ПОТРІЙНИХ НАПІВПРОВІДНИКОВИХ КВАНТОВИХ СТРУКТУР

Удосконалення технології вирощування напівпровідникових багатошарових структур сприяє створенню нового класу приймачів інфрачервоного випромінювання - детекторів на квантових структурах. Сучасний етап розробок ІЧ-приймачів характеризується активними дослідженнями матеріалів для різних наноструктур. Найбільш затребуваним напівпровідниковим матеріалом для створення традиційних ФД ІЧ-діапазону є $\mathrm{HgCdTe}$. Однак низький відсоток виходу придатних структур на основі $\mathrm{HgCdTe}$ підвищує вартість приладу. Розглянуто стан розробок ІЧ-детекторів на квантових структурах із застосуванням трикомпонентних напівпровідникових твердих розчинів. Представлені максимальні значення виявляючої здатності традиційних ФД і ФД на квантових структурах. Проведено аналіз параметрів для різних матеріалів і типів структур;

Ключові слова: надградкова структура, детектор інфрачервоного діапазону, надгратка, трикомпонентні напівпровідники, твердий розчин, фотодетектор, виявляюча здатність.

\section{Т. А. Саурова, И. П. Байда}

Национальный технический университет Украины «Киевский политехнический институт имени Игоря Сикорского», г. Киев, Украина

ИНФРАКРАСНЫЕ ДЕТЕКТОРЫ НА ОСНОВЕ ТРОЙНЫХ ПОЛУПРОВОДНИКОВЫХ КВАНТОВЫХ СТРУКТУР

Совершенствование технологии выращивания полупроводниковых многослойных структур способствует созданию нового класса приемников инфракрасного излучения - детекторов на квантовых структурах. Современный этап разработок ИК-приемников характеризуется активными исследованиями материалов для различных наноструктур. Наиболее востребованным полупроводниковым материалом для создания традиционных ФД ИК-диапазона является HgCdTe. Однако низкий процент выхода годных структур на основе $\mathrm{HgCdTe}$ повышает стоимость прибора. Рассмотрено состояние разработок ИК-детекторов на квантовых структурах с применением трехкомпонентных полупроводниковых твердых растворов. Представлены максимальные значения обнаружительной способности традиционных ФД и ФД на квантовых структурах. Проведен анализ параметров для различных материалов и типов структур.

Ключевые слова: сверхрешеточная структура, ИК детектор, сверхрешетка, трехкомпонентные полупроводники, твердый раствор, фотодетектор, обнаружительная способность.

Надійшла до редакиії 25 травня 2016 року

Рецензовано 09 червня 2016 року

(C) Saurova T., Baida I., 2016 